\title{
The Capability of Equisetum ramosissium and Typha angustifolia as Phytoremediation Agents to Reduce Nitrate-Phosphate Pollutants and Prevent Microcystis Blooming in Fresh Water Ecosystem
}

\author{
Viky Vidayanti $^{1}$, Catur Retnaningdyah ${ }^{1 *}$, Suharjono ${ }^{1}$ \\ ${ }^{1}$ Biology Department, Faculty of Mathematics and Natural Sciences, Brawijaya University, Malang, Indonesia
}

\begin{abstract}
The aim of this study is to find out the kind of hydromacrophyte composition having the highest capability to reduce nitrate-phosphate pollutant and Microcystis growth in phytoremediation media using Equisetum ramosissium, Typha angustifolia and the combination of both. Microcystis were obtained from Sutami reservoir, then being inoculated in a media grown by hydromacrophytes (E. ramosissium, T. angustifolia and both of the hydromacrophytes) in the batch culture system. The number of Microcystis was counted every day within fifteen days. Abiotic factors were observe, including the concentration of nitrate using brucine-colorimetry method and orthophosphate (dissolved phosphate) using stannous chloride-colorimetry method on day 0 , 6th, 12th and 15th. The growth rate of Microcystis carrying capacity and orthophosphate-nitrate levels among treatments were analysed by ANOVA test. The results showed that E. ramosissium and T. angustifolia in mono and polyculture techniques had similar potentiality to reduce the nitrate and ortophosphate. The concentrations of nitrate and orthophosphate decreased over $70 \%$ in the 6th day after incubation. All of the treatments were able to reduce the carrying capacity of Microcystis up to $46 \%$, but the growth rates were similar in all media, that is, around 97-170 cells/L/day.
\end{abstract}

Keywords: Equisetum ramosissium, Microcystis, nitrate, phosphate, Typha angustifolia

\section{INTRODUCTION}

Microcystis population blooming is one defect of eutrophication in aquatic ecosystem. Microcystis can experience a population explosion if the ratio of nitrate:phosphate in the water is 20,40 or 80 with the phosphate concentration of $0.4 \mathrm{mg} / \mathrm{L}$ and nitrate concentration of about $8-64 \mathrm{mg} / \mathrm{L}$ [1][2][3]. The existence of cyclic-peptide hepatotoxin in toxin of Microcystis (microcystin) as a liver tumour promoter is dangerous for human [4]. This toxin is a secondary metabolite encoded by non-ribosomal peptide synthetases (NRPS) and polyketide synthases (PKS) gene [5]. Meanwhile, the high population of Microcystis will decrease the oxygen dissolved in water, leading to the death of other aquatic organisms.

An effort to reduce nitrate as a source of nitrogen for Microcystis has been carried out by using the consortium of nitrate reducing bacteria. However, media Trypticase Soya Broth (TSB) was used for culturing the bacteria consortium

\footnotetext{
*Corresponding address:

Catur Retnaningdyah

Biology Department, Faculty of Math. and Natural Sciences, Brawijaya University, Jl. Veteran, Malang, Indonesia 65145 Email: catur@ub.ac.id
}

which contains high organic nitrogen that caused the high ammonia content in the aquatic environment [6]. Based on the above finding, another technique is needed to support this effort. Phytoremediation is environmentally friendly technology that uses plants to remove or render harmless pollutants from contaminated sites [7]. Plants can absorb toxic components and maintain the process in the metabolic system to be used as nutrient sources [3]. Equisetum ramosissium and Typha angustifolia are indigenous wetland plants from Indonesia and widely used as ornamental plants. Typha latifolia can uptake zinc $(\mathrm{Zn})$ and manganese $(\mathrm{Mn})$, then transfer them from root to other parts of the plants. Typha tolerates enhanced levels of metals in its tissue without serious physiological damage [8]. Equisetum ramosissium is able to accumulate lead $(\mathrm{Pb})$ and zinc $(\mathrm{Zn})$ in high concentrations in soil contaminated with heavy metals [9]. The aim of this study were finding out the hydromacrophyte composition having the highest capability to reduce nitrate-phosphate pollutant, and finding out the response of hydromacrophytes productivity and Microcystis growth in 
phytoremediation media using E. ramosissium, $T$. angustifolia and the combination of both.

\section{MATERIALS AND METHODS}

The experiment was conducted in December 2011 until April 2012. This study was an experimental using a complete randomized-block design. The study included eight treatments as presented in Table 1. The dependent variables in this study are the concentration of dissolved nitrate-phosphate after the incubation and the abundance of Microcystis, while the independent variable was hydromacrophyte.

Table 1. Treatment combination

\begin{tabular}{ll}
\hline Without Microcystis addition & Microcystis addition \\
\hline Without hydromacrophyte & With hydromacrophyte \\
E. ramosissium & E. ramosissium \\
T. angustifolia & T. angustifolia \\
E. ramosissium + T. angustifolia & E. ramosissium $+T$. angustifolia \\
\hline
\end{tabular}

Microcystis samples were taken horizontally parallel from water surface in Reservoir Sutami, Malang, East Java, Indonesia, using a water sampler one-litre capacity. The water was filtered using plankton net to get Microcystis. The sample was counted to obtain $5 \times 108$ cells.mL-1 and used as inoculums. E. ramosissium was obtained from Splendid flower market, Malang, T. angustifolia was taken from Sidoarjo and the soil was obtained from wetland area around Malang. The study was conducted at the Laboratory of Ecology and Animal Diversity, Microbiology Laboratory and Glasshouse, Department of Biology, Faculty of Mathematics and Natural Sciences, Brawijaya University, Malang. The determination of potential hydromacrophyte was carried out in tubs and aquariums with the addition of Sutami reservoir water $15 \mathrm{~L}$ for tub and $5 \mathrm{~L}$ for aquarium. The water was enriched by phosphate $\left(\mathrm{K}_{2} \mathrm{HPO}_{4}\right) 0.4$ ppm.L-1 and nitrate $\left(\mathrm{NaNO}_{3}\right) 16$ ppm.L-1. The soil was added as much as $20 \mathrm{~kg} / \mathrm{tub}$ and 6 $\mathrm{kg} /$ aquarium. Each tub and aquarium were inoculated by hydromacrophyte like in Table 1 . Each treatment was incubated in glasshouse for 15 days using batch culture system.

Abiotic factors were observed in this study, including the concentration of dissolved nitratephosphate, and measured in every three days. The nitrate concentrations were measured by using brusin-colorimetric method [10]. The dissolved phosphate concentrations were measured by using stannous chloridecolorimetric method [11].

The Microcystis abundance was counted every day for 15 days by filtering $100 \mathrm{~mL}$ of water treatment using plankton net with 406 pores per inch. The samples were boiled for 6 minutes and cooled, and the number of cells in haemocytometer $1 \times 10^{-4} \mathrm{~cm}^{3}$ volume was counted by using a binocular microscope at $400 \mathrm{x}$ magnifications and calculated by Formula 1 [12].

Cells number counted $\mathrm{x}$ volume concentration $(\mathrm{ml})$ $1 \times 10^{-4} \mathrm{~cm}^{3} \mathrm{x}$ volume filtered $(100 \mathrm{ml})$

The Microcystis abundance data for 15 days was used to determine the maximum growth rate of Microcystis based on the Formula 2 [13]. The carrying capacity $(\mathrm{K})$ is the maximum population during observation.

$$
\begin{aligned}
& \hline \mathrm{g}=\left(\ln \mathrm{N}_{\mathrm{t}}-\ln \mathrm{N}_{0}\right) / \mathrm{t} \\
& \mathrm{Nt}: \text { The highest Microcystis population after incubation } \\
& \mathrm{N} 0: \text { The initial number of Microcystis population } \\
& \mathrm{t} \quad: \text { The time required to achieve the highest Microcystis } \\
& \text { population }
\end{aligned}
$$

The data were analyzed by using the analysis of variance (ANOVA) test to determine the effect of hydromacrophyte treatment and incubation time on nitrate-phosphate solute concentration, on growth rate, and on the carrying capacity of Microcystis. If the data were significantly different, then Tukey test for homogeneous variants or $\mathrm{T}$ test for heterogeneous variants with significance level $5 \%$ was conducted by using SPSS 16.0 for Windows.

\section{RESULT AND DISCUSSION}

The decreasing percentage of nitrate and orthophosphate concentrations turned out to increase in every observed day. The most maximum decreasing concentration of nitrate and orthophosphate was above $95 \%$ as evident from day 12th and 15th (Figure 1b, c, e and f). Both of hydromacrophyte on mono or polyculture techniques had similiar potentiality to reduce nitrate and orthophosphate. The other research by using other plants shows similar result. Water hyacinth (Eichhornia crassipes) could also reduce nitrate from 1183 and $1120 \mathrm{mg} / \mathrm{L}$ to 4.4 and $0.6 \mathrm{mg} / \mathrm{L}$, and phosphate from 46.4 and $31.2 \mathrm{mg} / \mathrm{L}$ to 1.1 and $0.1 \mathrm{mg} / \mathrm{L}$, respectively [14]. Spirodela punctata could uptake $\mathrm{N}$ and $\mathrm{P}$ until $0.955 \mathrm{mg} \mathrm{N} /$ liter/hr and $0.129 \mathrm{mg} \mathrm{P} /$ liter/hr 
[15]. Fat duckweed - Lemna gibba was also found to reduce $\mathrm{N}, \mathrm{NH}_{3}$ and $\mathrm{P}$ in waste water by $100 \%, 82.0 \%$ and $64.4 \%$, respectively in 8 days [16].

The concentrations of dissolved nitrate and phosphate or orthophosphate on all media began to decline on day 6th. Generally, the concentrations of nitrate and orthophosphate always decreased in every observed day until reaching limiting value on day 15 th, that is, less than $0.3 \mathrm{ppm}$ for nitrate (Figure 1c) and 0.01 ppm for orthophosphate (Figure 1f). The decrease of nitrate and orthophosphate concentration on control media is not only caused by Microcystis but also by the presence of algae Cladophora and Phitophora. These algae are included in the family Cladophoraceae, widely grown in fish ponds and have chloroplasts
[17][18]. Nitrogen concentrations above 10 $\mathrm{mg} / \mathrm{L}$ and phosphorus above $0.1 \mathrm{mg} / \mathrm{L}$ can lead to algae growth to a population explosion. The ratio of phosphorus and nitrogen absorption by organism is 1:16 with the phosphorus as limiting factor. Thus, it can be concluded that phosphorus's requirement of organism is lower than nitrate [19]. The decrease in the concentration of nitrate and orthophosphate can be an indicator of the utilization of two compounds by Microcystis, hydromacrophyte and algae. The decrease in the concentration of nitrate and orthophosphate can also be caused by bacteria that are found capable to reduce nitrate and orthophosphate in the media. The presence of microorganisms such as algae and bacteria that grow in the medium will take the nutrient in these media [20].
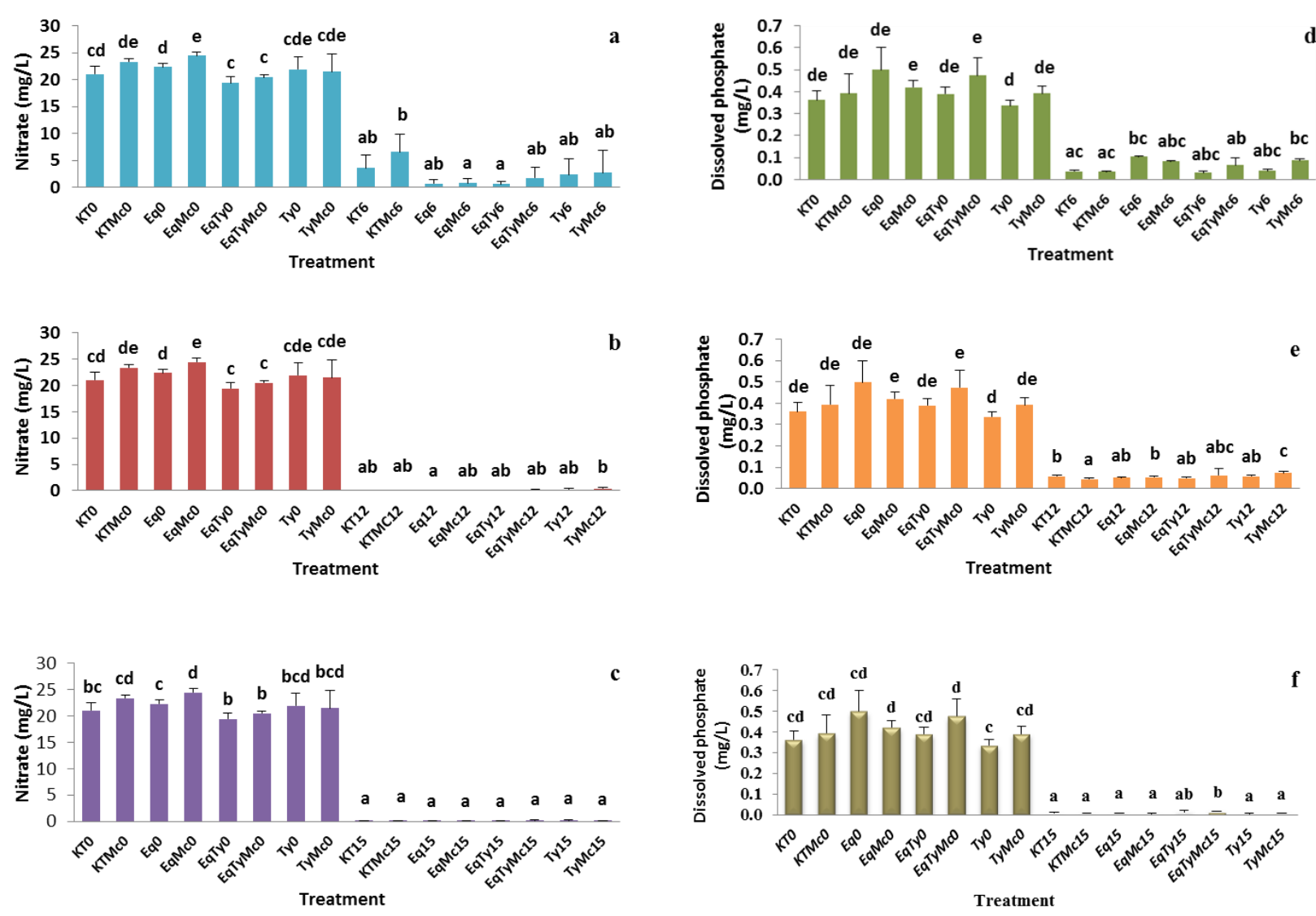

Figure1. Comparison of nitrate $(\mathrm{a}, \mathrm{b}, \mathrm{c})$ and orthophosphate $(\mathrm{d}, \mathrm{e}, \mathrm{f})$ concentrations on day $0,6^{\text {th }}, 12^{\text {th }}$ and $15^{\text {th }}$ after incubation. Note : 1. KT: Control; Mc: Microcystis; Eq: E. ramosissium; Ty: T. angustifolia; Eq Ty: E. ramosissium-T. angustifolia; 2.The same notation show non significance difference based on ANOVA test and T test

Orthophosphate and nitrate in the media were frequently used as a source of nutrients for cell growth and the development of hydromacrophyte and algae rather than Microcystis. This is supported by the high value of the hydromacrophyte growth, increasing the population of algae (Cladophora and Phitophora), while the concentration of nitrateorthophosphate and the abundance of Microcystis cells decreased (Figure 8). Phosphorus is a component of nucleic acids that control protein synthesis, DNA backbone and the constituent components of the adenosine phosphate which serves as a source of energy for 
intracellular transport. Nitrogen is needed by cells and its part of amino acids. The presence of nitrate reductase enzyme will convert nitrate to ammonia [21].

Autotrophs organisms have chlorophyll to do photosynthesis. Light will be used directly in the process of electron transfer through the reduction of nicotinamide adenine dinucleotide phosphate (NADP) to NADPH. Electrons are extracted from water (photosystem II) and transported through to the next cycle of quinone used in photosystem I. NADPH will be used subsequently to form glucose. Plants get nitrogen in the form of nitrate $\left(\mathrm{NO}_{3}{ }^{-}\right)$. Furthermore, nitrate assimilation will occur in two steps 1 . The reduction of nitrate to nitrite $\left(\mathrm{NO}_{2}{ }^{-}\right)$by nitrate reductase in the cytosol and 2. The reduction of nitrate to ammonium $\left(\mathrm{NH}_{4}+\right)$ by nitrate reductase in chloroplasts or prolastid [22]. Ammonium is toxic, so it will be converted into glutamine, glutamic acid, and asparagine. Plants absorb phosphorus in the form of orthophosphate ion. In the cell plant, $\mathrm{P}$ ions are in the form of Pi. Plant cells will also do respiration to get energy. Gradual reactions in respiration are grouped into four main processes, namely, (1) Glycolysis, (2) Citric acid cycle, (3)

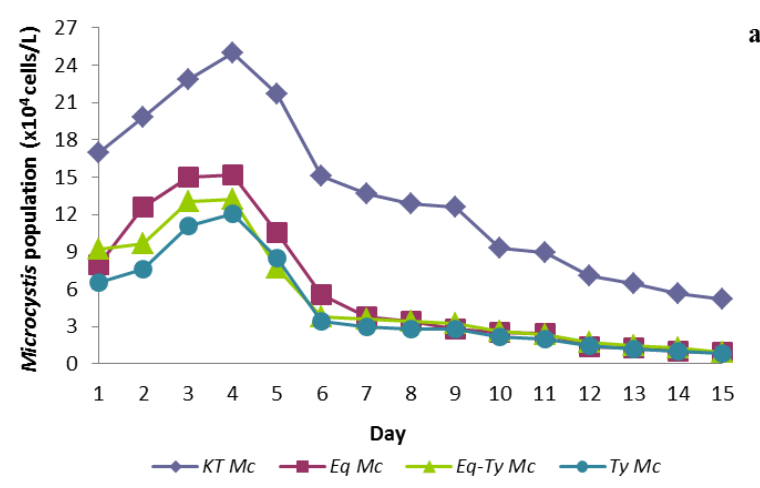

Pentose phosphate path, and (4) Oxidative phosphorylation to produce ATP [23].

Based on Figure 2a, Microcystis populations did not go through lag phase or adaptation phase, but directly entered exponential phase (on day 1 st until 4th) and continued to death phase (on day 5th). The number of dead cells increased, which was influenced by nutrient conditions, environment condition and the types of microorganisms [24]. The number of Microcystis cell population in the control media was higher than in the media for hydromacrophyte treatment because of the competition between Microcystis and hydromacrophyte to get nitrate and orthophosphate. In addition, the hydromacrophyte canopy would block light from beaming into the water surface. Cyanobacteria are more common in areas with high light intensity, especially in mid-dry. Microcystis are widely spread on the water surface or at a certain depth in which light can penetrate to do photosynthesis [25]. The absorption of light by canopy not only reduces the intensity of light but also changes the spectrum of transmitted light. The photosynthesis is greatly influenced by the presence of light, so the photosynthesis process will be inhibited if there is no light or there is a change on the light spectrum [26].

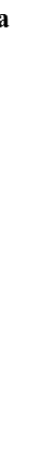

Figure 2. Growth pattern of Microcystis (a), carrying capacity and maximum growth rate (b) during observation. Note: 1 . KT: Control; Mc: Microcystis; Eq: E. ramosissium; Ty: T. angustifolia; Eq Ty: E. ramosissium-T. angustifolia; 2.The same notation show non significance difference based on ANOVA test

The maximum growth rates $(\mathrm{g})$ of the Microcystis in all media were ranging from $97-$ 170 cells/L/ day (Fig. 2b). The statistical analysis showed that the rate of Microcystis cells growth in the control and treatment media hydromacrophyte were similiar. The maximum amount of the highest population of Microcystis cells present in the control media at 25 x104 cells/L (Figure 2b). Based on the statistical analysis, it was revealed that the $\mathrm{K}$ value was significantly different between control media and the $\mathrm{K}$ value of hydromacrophyte treatment. The Microcystis in media control had no competitor in getting the main nutrients, especially nitrates and phosphates. The hydromacrophyte treatment could reduce the carrying capacity of the media up to $46 \%$.

\section{CONCLUSION}

This study has proven that E. ramosissium and T. angustifolia in mono and polyculture techniques have similar potentiality to reduce the nitrate and ortophosphate. The concentrations of nitrate and orthophosphate in this study decreased over 70 $\%$ in 6th day after incubation. All of the 
treatments were able to reduce the carrying capacity of Microcystis up to $46 \%$, but the growth rates were similar in all media, that is, about 97 170 cells/L/day.

\section{ACKNOWLEDGEMENTS}

This research is supported by Directorate General of Higher Education (DIKTI), Ministry of National Education. We are also grateful to Zidny Furaidah for her valuable help in conducting this research.

\section{REFERENCES}

1. Retnaningdyah, C, Suharjono, Soegianto A, Irawan B (2010) Daya Dukung Laju Pertumbuhan Microcystis Hasil Isolasi dari Waduk Sutami pada Berbagai Variasi Konsentrasi Nitrat Fosfat dalam Medium Selektif B-12. Biota 15 (3): 354-362.

2. Retnaningdyah, C, Suharjono, Soegianto A, Irawan B (2010) Blooming Stimulation of Microcystis in Sutami Reservoir Using Nutrients Nitrate and Phosphate in Different ratio. Journal Tropical Life Science 1 (1): 42-47.

3. EPA (2000) Introduction to Phytoremediation. National Risk Management Research Laboratory Office of Research and Development US Environmental Protection Agency. Ohio, page 3.

4. Rolland, A, Bird DF, Giani A (2005) Seasonal Changes in Composition of the Cyanobacterial Community and the Occurrence of Hepatotoxic Blooms in the Eastern Townships, Quebec, Canada. Journal of Plankton Research 27: 683694.

5. Borner, T, Dittmann E (2005) Molecular Biology of Cyanobacterial Toxins: Genetic Basis of Microcystin Production. Springer. Dordrecht, Vol III page 25-40.

6. Retnaningdyah, C, Marwati U, Suharjono, Ajijah N, Marjono, Soegianto A, Irawan B (2009) Potensi Formulasi Bakteri Pereduksi Nitrat Waduk Sutami Malang dalam Menghambat Pertumbuhan Microcystis. Berkala Penelitian Hayati 14 (2): 209-217

7. Cluis, C (2004) Junk-greedy Greens: phytoremediation as a new option for soil decontamination. BioTeach Journal 2: 61-67.

8. Sasmaz, A, Obek E, Hasar H (2008) The accumulation of heavy metals in Typha latifolia $\mathrm{L}$ Grown in a stream carrying secondary effluent. Eco Eng Journal 33: 278-284.

9. Anh, BTK, Kim DD, Kien NT, Anh DT (2011) Phytoremediation Potential of Indigenous Plants from Thai Nguyen Province, Vietnam. Journal Environmental Biology 32: 257-262.

10. Narayana, B, Sunil K (2009) A Spectrophotometric Method for the
Determination of Nitrite and Nitrate. Eurasian Journal of Analytical Chemistry 4(2): 204-214.

11. Feiser, LF, Feiser M (1967) Reagents for Organic Synthesis. Wiley. New York.

12. Joung, SH, Kim CJ, Ahn KY, Boo BM, Oh HM (2006), Simple Method for a Cell Count of Colonial Cyanobacterium Microcystis sp. Microbiology Journal 562-565.

13. Chen, F, Xie P, Qin B (2007) Different Competitive Outcomes among Four Species of Cladocerans under Different Alga Combinations of Colonial Microcystis spp and Green Alga Scenedesmus obliquus. Hydrobiologia 581: 209-215.

14. Akinbile, CO, Yusoff MS, Shian LM (2012) Leachate Characterization and Phytoremediation Using Water Hyacinth (Eichorrnia crassipes) in Pulau Burung, Malaysia. Bioremediation Journal 16 (1): 9-18.

15. Cheng, J, Ben A, Bergmann BA, Classen JJ, Stomp AM, Howard JW (2002) Nutrient recovery from swine lagoon water by Spirodela punctata. Bioresource Technology 81 (1): 81-85.

16. El-Kheir WA, Ismail G, El-Nour A, Tawfik T, Hammad D (2007) Assessment of the efficiency of duckweed (Lemna gibba) in wastewater treatment. International Journal of Agriculture and Biology 5: 681-689.

17. Promya, J, Chitmanat C (2011) The effects of Spirulina platensis and Cladophora Algae on the Growth Performance, Meat Quality and Immunity Stimulating Capacity of the African Sharptooth Catfish (Clarias gariepinus). International Journal Of Agriculture Biology 13 (1): 77-82.

18. Singh, AP, Chaudhary BR (2011) Allelopathic Potential of Algal Weed Pithophora oedogonia (Mont) Ittrock on the Germination and seedling Growth of Oryza sativa L. Botany Research International 4 (2): 36-40.

19. Radojevic, M, Bashkin VN (1999) Practical Environmental Analysis The Royal Society of Chemistry. Cambridge.

20. Prescott, L, Harley JP, Klein DA (2003) Microbiology. McGraw-Hill. New York.

21. Reynolds, CS (2006) The Ecology of Phytoplankton. Cambridge University Press. Cambridge.

22. Hortensteiner, S, Feller U (2002) Nitrogen metabolism and remobilization during senescence. Journal of Experimental Botany 53: 927-937.

23. Taiz, L, Zeiger E (2010) Plant Physiology. Sinauer Associates. Sunderland

24. Madigan, MT, Martinko JM, Parker J (2003) Brock Biology of Microorganism $10^{\text {th }}$ Ed. Prentice-Hall. New Jersey.

25. Retnaningdyah, C, Marwati U, Soegianto A, Irawan B (2011) Media Pertumbuhan, Intensitas Cahaya dan Lama Penyinaran yang Efektif untuk Kultur Microcystis Hasil Isolasi dari Waduk Sutami di Laboratorium. Jurnal Biosains Pascasarjana 13 (2): 123-130. 
26. Yerima, JB, Esther MA, Madugu JS, Muwa NS, Timothy SA (2012) The effect of Light Color (wavelength) and Intensity on Vegetable Roselle (Hibiscus Sabdariffa) growth. Scholarly Journal of Scientific Research Essay writing 1(2): 25-35. 